\title{
Diel feeding behaviour of krill in the Gerlache Strait, Antarctica
}

\author{
Santiago Hernández-León ${ }^{1, *}$, Agustín Portillo-Hahnefeld ${ }^{1}$, Carlos Almeida ${ }^{1}$, \\ Pierrick Bécognée ${ }^{1}$, Isabel Moreno ${ }^{2}$
} ${ }^{1}$ Biological Oceanography Laboratory, Facultad de Ciencias del Mar, Universidad de Las Palmas de Gran Canaria,
Campus Universitario de Tafira, 35017 Las Palmas de Gran Canaria, Canary Islands, Spain

${ }^{2}$ Departamento de Biología Ambiental, Facultad de Ciencias, Universidad de las Islas Baleares, Ctra. De Valdemossa, 07071 Palma de Mallorca, Spain

\begin{abstract}
Abundance, gut fluorescence and gut content of juvenile krill Euphausia superba (15 to $20 \mathrm{~mm}$ ) were measured during a diel cycle in the Gerlache Strait (Antarctic Peninsula). Krill remained in the upper layers (0 to $100 \mathrm{~m}$ ) during the day and migrated downward below this depth during the night, coinciding with the vertical ascent of the copepod Metridia gerlachei to shallower layers. Krill fed on phytoplankton during the day (as deduced from gut fluorescence measurements), whereas they switched to carnivory during the night (as deduced from gut contents). The vertical migration and the feeding behaviour of krill agree with different observations in the literature and gives an additional explanation to the observed inverse relationship between krill and non-krill zooplankton. The fact that krill is able to prey on mesozooplankton suggests that euphausiids can exert a top-down effect which structures the plankton community of Antarctic waters.
\end{abstract}

KEY WORDS: Feeding $\cdot$ Vertical distribution $\cdot$ Zooplankton $\cdot$ Antarctica Resale or republication not permitted without written consent of the publisher

\section{INTRODUCTION}

An important milestone of bio-oceanographic research in polar waters is the study of the structure and dynamics of plankton communities as the basis to understand its economy (i.e. energy flux) and how changes in environmental conditions can affect population dynamics. In Antarctic waters, Euphausia superba (hereafter 'krill') have an important role in the presence/absence and on the development of many species of birds and mammals. However, little is known about the cues for aggregation, swarm formation, vertical migration, distribution and behaviour of these crustaceans.

Historically, euphausiids have been considered as efficient grazers and most of the studies of their energy budget have been focused on their impact on the phytoplankton crop and primary production (e.g. Que-

*E-mail: santiago.hernandez-leon@biologia.ulpgc.es tin et al. 1994, Pakhomov et al. 1997, among others). However, krill are able to prey upon other zooplanktonic organisms such as copepods (Price et al. 1988, Hopkins \& Torres 1989, Granéli et al. 1993, Nishino \& Kawamura 1996, Atkinson \& Snÿder 1997) as well as to be cannibalistic (Nishino \& Kawamura 1994). On the basis of energetic requirements, it has been suggested that E. superba has to consume a much larger proportion of heterotrophic carbon than previously supposed (Perissinotto et al. 1997). Cripps et al. (1999) also observed krill surviving on low algal biomass areas in the South Georgia region, suggesting that they probably resorted to carnivory on copepods rich in polyunsaturated fatty acids (PUFA). During the same cruise, it was found that protozoans and copepods supplied most of their carbon intake (Atkinson \& Snÿder 1997). The latter authors also found that krill preyed upon copepods in the range of 1 to $3 \mathrm{~mm}$ (the most common size of large copepods in Antarctic waters) at the fastest rates. Moreover, Perissinotto et al. (2000) 
observed that the heterotrophic component of the mass gut content accounted for an average value of $79 \%$.

It has been shown that krill can switch from algal to animal food and that there is a positive electivity on copepods when they are exposed to both kinds of food (Granéli et al. 1993). Recently, Atkinson et al. (1999) showed that areas of persistently high krill abundance were characterised by exceptionally few copepods. Copepods also appeared to live deeper and to make more extensive vertical migrations when krill were present. Therefore, based on experimentally obtained predation rates on copepods and on krill biomass, they suggested that copepod numbers can be controlled by a combination of competition and predation by krill.

During 2 surveys in December 1991 and February 1993, very low values of zooplankton $(<14 \mathrm{~mm})$ biomass were found around the Antarctic Peninsula (Hernández-León et al. 1999, 2000) and most of the large copepod abundance was found to be the strong diel vertical migrant Metridia gerlachei (see Lopez \& Huntley 1995). To study the vertical distribution of krill Euphausia superba and the migratory pattern of $M$. gerlachei, we sampled the abundance of those organisms in the upper $600 \mathrm{~m}$. We also analysed animals for gut content in order to investigate their feeding behaviour. The results presented below indicate that krill can play an important role in structuring the plankton communities in Antarctic waters as deduced from their switch to carnivory and the long-term changes in krill and copepods in these waters.

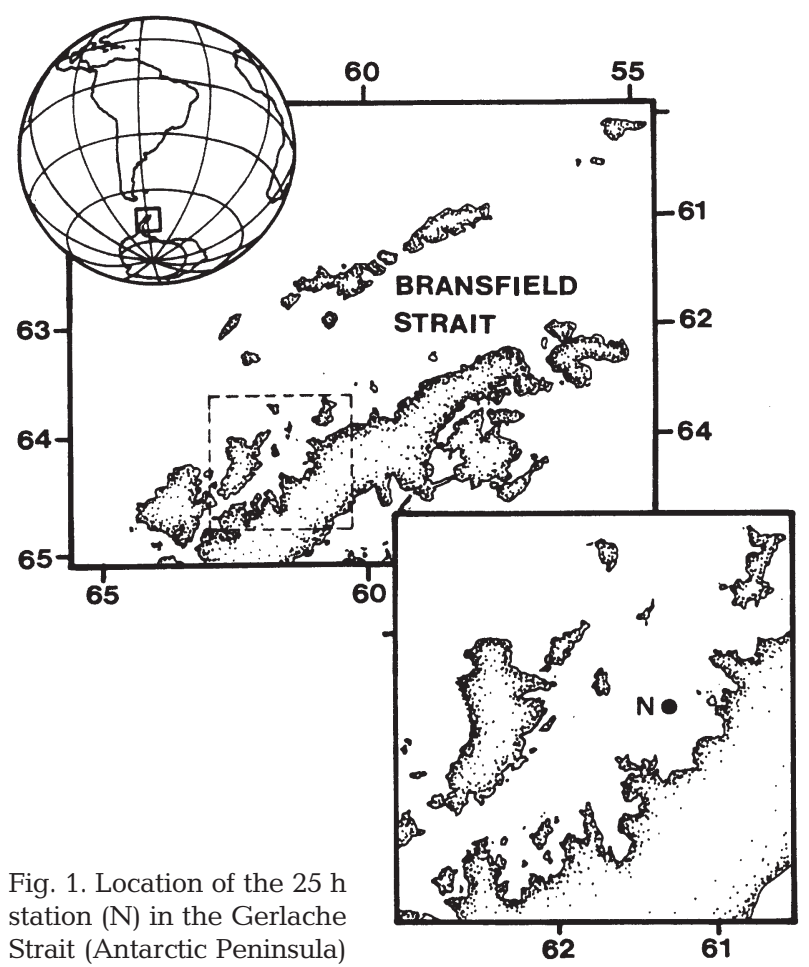

\section{MATERIALS AND METHODS}

Zooplankton abundance was sampled from 9 to 10 February 1993, in the waters between the Gerlache and Bransfield Straits (Fig. 1) during a 25 h station. Samples were obtained by means of a $1 \mathrm{~m}^{2}$ BIONESS net (Sameoto et al. 1980) equipped with 10 nets of $200 \mu \mathrm{m}$ mesh size. The net was deployed every $2 \mathrm{~h}$ (except at 19:00 $\mathrm{h}$ on the first day, where the interval was $3 \mathrm{~h}$ ) in order to sample the 0 to 20,20 to 50,50 to 100,100 to 200,200 to 400 and 400 to $600 \mathrm{~m}$ layers. The net filtered between 86 and $437 \mathrm{~m}^{3}$ of seawater in the upper layer and between 610 and $916 \mathrm{~m}^{3}$ in the lower layer. Temperature and salinity were obtained by using a CTD sensor, and samples for chlorophyll were obtained with Niskin bottles.

To study the feeding behaviour of euphausiids and copepods, we measured the gut fluorescence (Mackas \& Bohrer 1976) and stomach contents of krill during a diel cycle at the different depths. Both measurements might have been affected in animals trapped on the cod-end of the net. Atkinson et al. (1992a) found that samples taken at different depths in a LonghurstHardy Plankton Recorder (LHPR) did not introduce errors other than those described in the literature, i.e. pigment degradation and partial gut evacuation. The BIONESS net do not preserve the animals motionless as in the LHPR net. Therefore, the possibility of ingestion during the catch exists, although it must affect gut fluorescence and stomach content in all the samples. However, although krill were caught by day and night in the upper layers, the gut fluorescence appeared higher only during the day (see below). The inverse can be said of the stomach content. Thus, the variability found should be related to feeding prior to the capture.

Between 5 and 15 adults or CV-stages of Metridia gerlachei, and 1 to 5 specimens of the most abundant size class (15 to $20 \mathrm{~mm}$ ) of krill were immediately sorted after the net arrived on board for gut content analysis. Gut fluorescence was determined using the procedure described by Morales et al. (1990). Individuals were placed in a test tube with $10 \mathrm{ml}$ of $90 \%$ acetone and stored at $-20^{\circ} \mathrm{C}$ (for $24 \mathrm{~h}$ ) for gut pigment analysis. Fluorescence of the samples was measured before and after acidification with 2 drops of $10 \% \mathrm{HCl}$ in a fluorometer (Model 10, Turner Designs, Sunnyvale, CA) previously calibrated with pure chlorophyll (Yentsch \& Menzel 1963). Pigments were calculated with the equations given by Strickland \& Parsons (1972) slightly modified to:

$$
\begin{aligned}
\text { Chlorophyll } & =\mathrm{k}\left(F_{\mathrm{o}}-F_{\mathrm{a}}\right) / N \\
\text { Pheopigments } & =\mathrm{k}\left(\mathrm{R} F_{\mathrm{a}}-F_{\mathrm{o}}\right) / N
\end{aligned}
$$


where $\mathrm{k}$ is the machine calibration constant, $F_{\mathrm{o}}$ and $F_{\mathrm{a}}$ are the fluorescence readings before and after acidification, and $\mathrm{R}$ is the acidification coefficient and $N$ is the number of individuals. Gut pigment concentration in this study refers to the addition of chlorophyll and pheopigments. Because no attempt was made to calculate grazing rate, no correction was made for background fluorescence and for pigment loss.

In the laboratory, Euphausia superba and Metridia gerlachei were sorted and counted; the former were also measured and grouped in $1 \mathrm{~mm}$ intervals. The stomach content of E. superba was analysed by microscopic examination of the suspended gut content on slide preparations. The hindgut of these organisms (15 to $20 \mathrm{~mm}$ ) was too small and no attempt was made in order to analyse its content. Items were examined at magnification of $\times 40$ to $\times 600$ depending on their sizes. Counts were made of all the crustacean fragments (mainly appendages) within the whole preparation.

\section{RESULTS}

Temperature and salinity showed low variability during the diel cycle studied and chlorophyll was $>1 \mathrm{mg} \mathrm{m}^{-3}$ in the upper $10 \mathrm{~m}$ layer (Fig. 2). The vertical distribution study of Metridia gerlachei showed high abundance at the 400 to $600 \mathrm{~m}$ layer during the day, with the population ascending during the night to shal- lower layers where their gut fluorescence increased (Fig. 3) as the result of feeding in the surface chlorophyll-rich layer. This higher gut content also remained during their downward migration at dawn, decreasing at the end of the cycle studied. Numbers of other large copepods such as Calanoides acutus and Rhincalanus gigas were very low, and the only pattern observed was the higher gut pigment content at night (not shown).

The euphausiids sampled by the BIONESS net were measured (3380 individuals, Fig. 4) and 3 size classes with a normal distribution were obtained ( 7 to 13,15 to 25 and 26 to $36 \mathrm{~mm}$ ). Higher abundance was found during night, probably as a consequence of net escapement during daylight hours (Holm-Hansen \& Huntley 1984, Mathew 1988, Nordhausen 1994). The vertical distribution of the 15 to $25 \mathrm{~mm}$ size class and of all euphausiids during the study (Fig. 5) showed that they stayed in the 20 to $100 \mathrm{~m}$ layer during the day, but they dispersed during the night, appearing in the 200 to 400 and 400 to $600 \mathrm{~m}$ depths, and at the surface at the end of the night. The gut fullness of those organisms was rather low, probably due to degradation to nonfluorescent products which have been estimated in the range of 67 to $90 \%$ of the total pigment ingested (Perissinotto et al. 1997). However, they showed a higher pigment content during daylight hours at the shallower layers (0 to $100 \mathrm{~m}$, filled symbols in Fig. 6A) and a sharp decrease during the night in all depths.
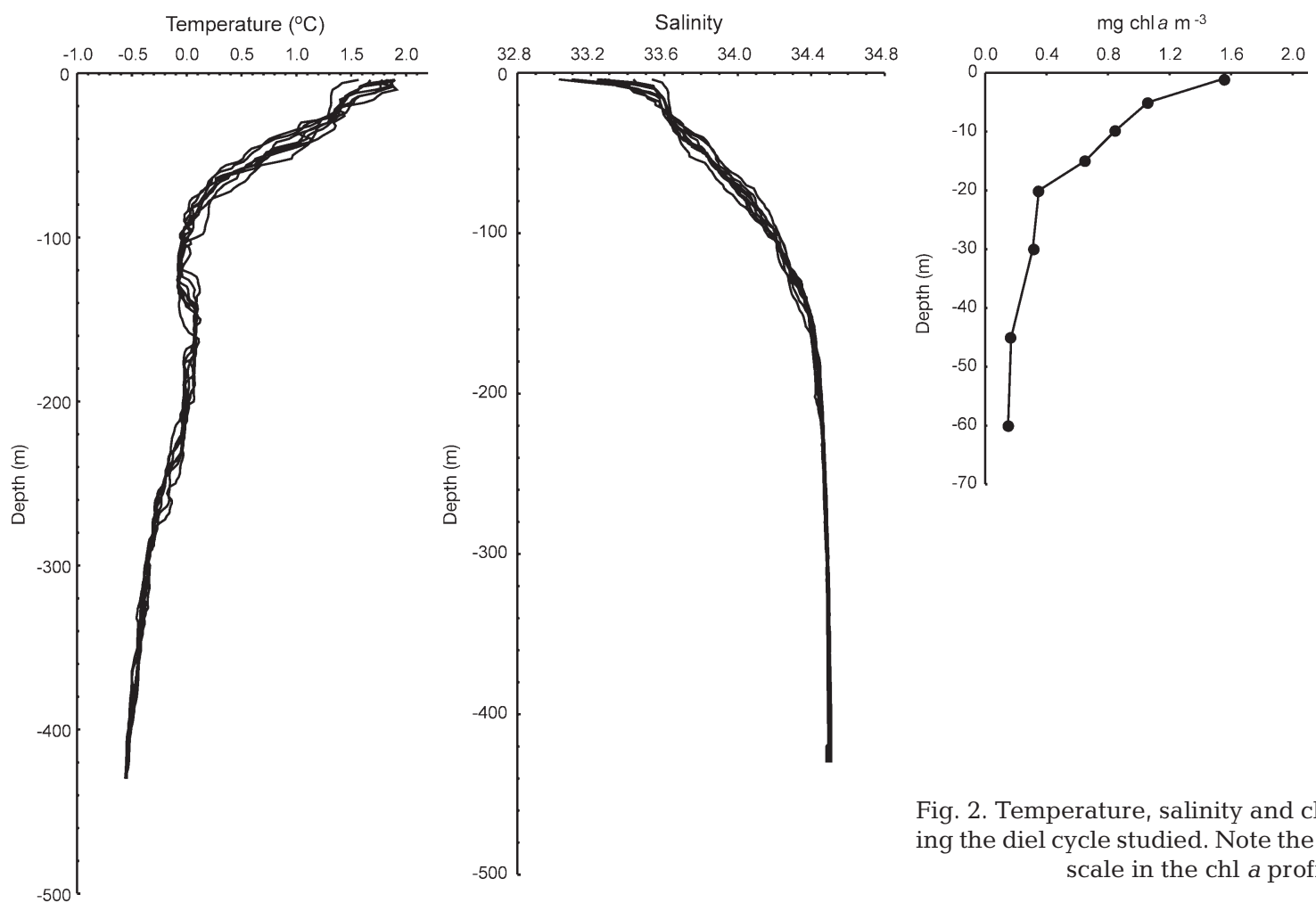

Fig. 2. Temperature, salinity and chl a values during the diel cycle studied. Note the different depth scale in the chl a profile 

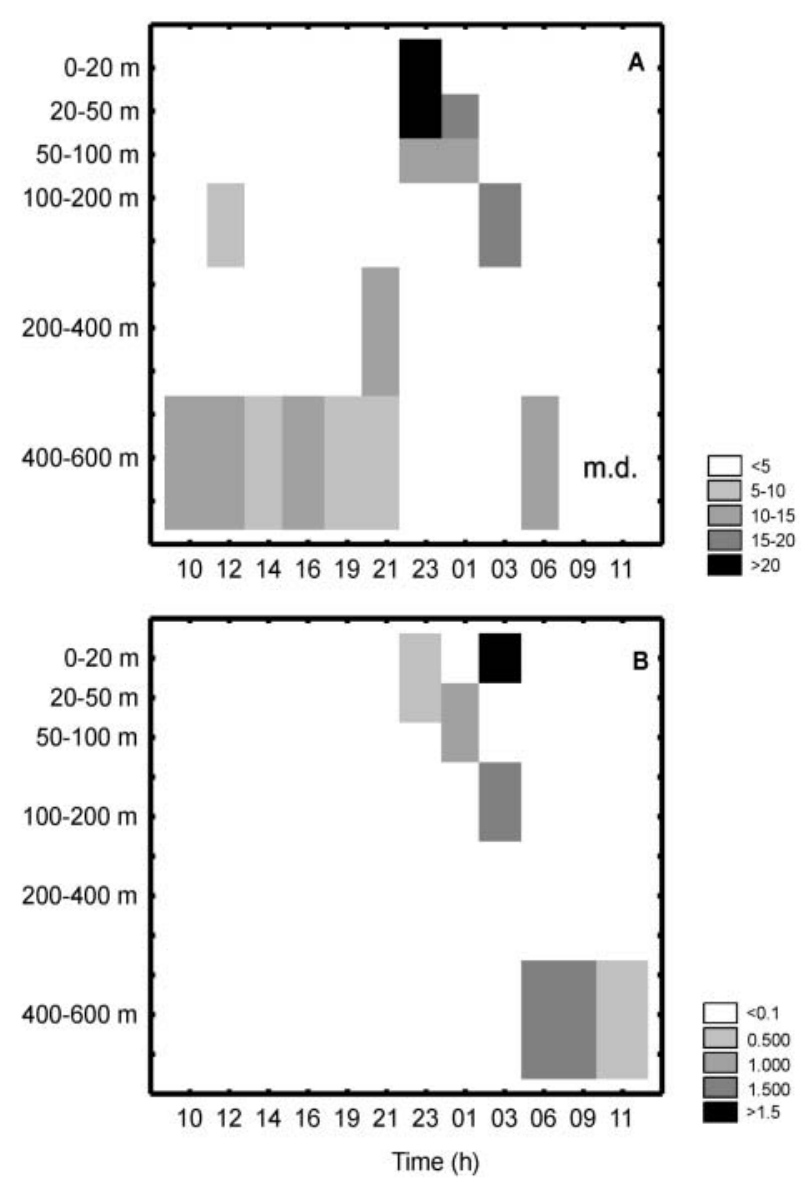

Fig. 3. Metridia gerlachei. (A) Abundance (ind. $\mathrm{m}^{-3}$ ) and (B) gut pigment content (ng ind. ${ }^{-1}$ ). Data were obtained in all the layers sampled and the absence of shading indicates low values, except at the deeper layer in the 2 last samplings in (A) in which copepods were not counted because of preservation failure (md stands for missing data). Observe their vertical migration and the increase in gut pigment content during twilight and night (complete dark from 23:00 to 03:00 h) at the shallower layers and the presence of high gut pigment levels during the morning at the deeper layer

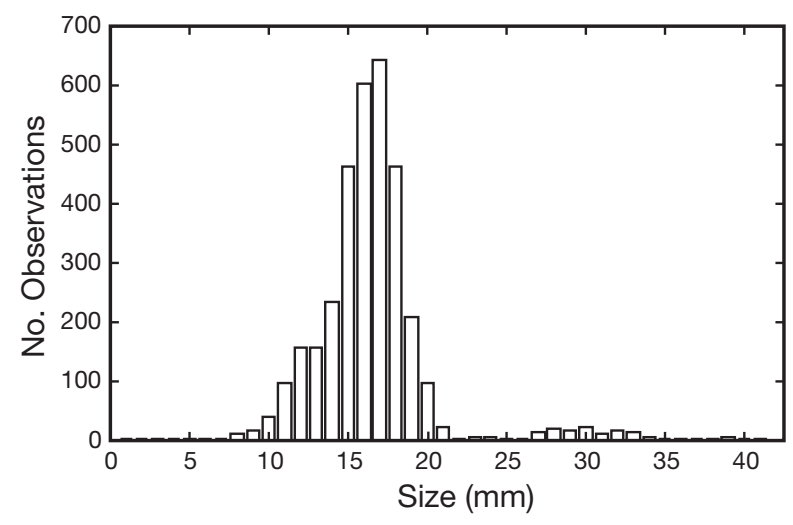

Fig. 4. Size distribution of Euphausia superba captured during the diel cycle
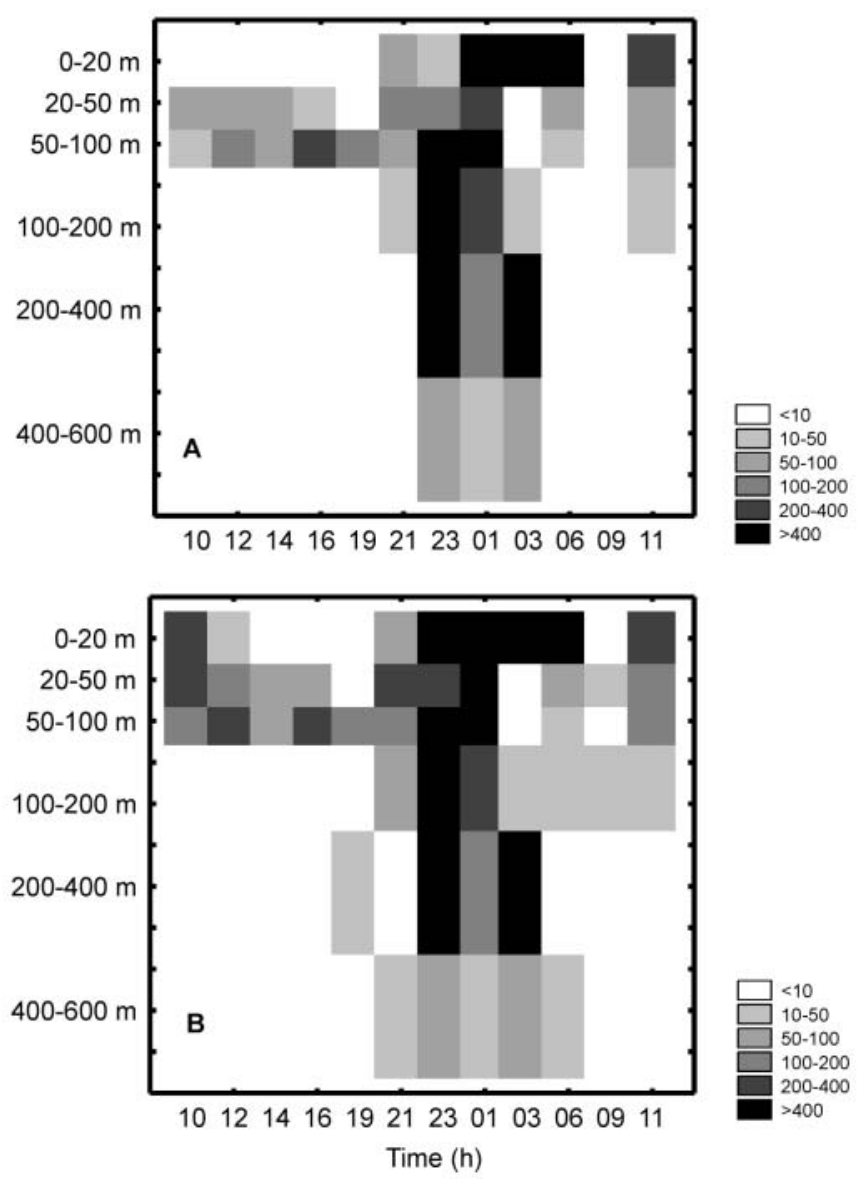

Fig. 5. Euphausia superba. Vertical distribution (ind. $\mathrm{m}^{-3}$ ) of (A) the 15 to $25 \mathrm{~mm}$ class and (B) of all specimens. Data were obtained in all the layers sampled and the absence of shading indicates low values. Observe the deeper distribution of organisms during the night

The gut content analysis of krill also revealed a significant (ANOVA, $\mathrm{p}<0.05$ ) higher number of crustacean fragments during the night (Fig. 6B) coinciding with the decrease in gut fluorescence at all depths during that time.

\section{DISCUSSION}

The vertical distribution of euphausiids and copepods as well as their nocturnal movements observed during the study are consistent with previous research in the area. Acoustic techniques have revealed the presence of 2 layers in Antarctic waters (Pakhomov et al. 1994, Weeks et al. 1995). A surface layer corresponding to large organisms such as euphausiids and a deeper one of smaller organisms below $200 \mathrm{~m}$, appeared as an homogeneous and diffuse scattering layer. The latter layer has been observed to follow the 

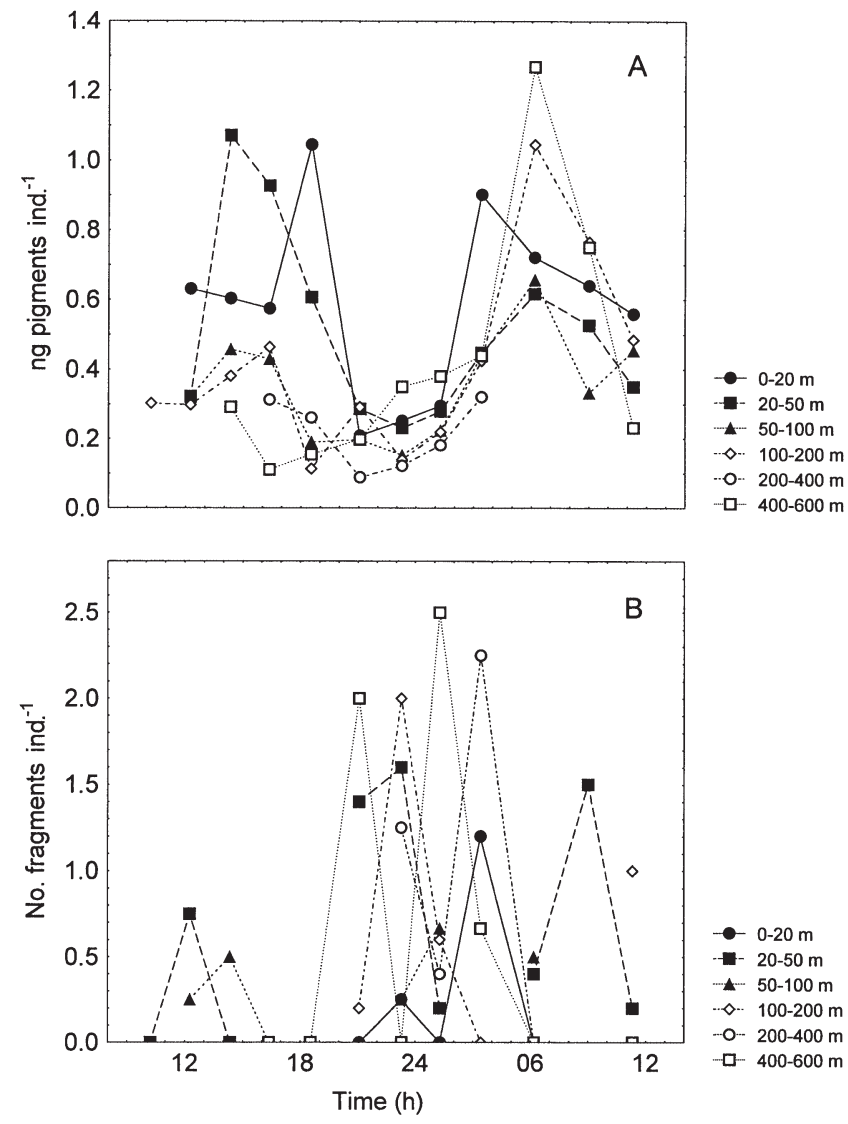

Fig. 6. Euphausia superba. (A) Gut pigment content and (B) crustacean fragments in the gut of juveniles. Observe the lower values of gut pigment during the twilight and dark hours coinciding with an increase in crustacean fragments

distribution of illumination (Weeks et al. 1995), ascending during night (Pakhomov et al. 1994). At this time, both layers were less evident and appeared uniformly distributed in the water column (Pakhomov et al. 1994). This pattern agrees with observations that the number of krill swarms is higher during daylight hours than during the dark period (Everson 1982, Siegel 1988, Demer \& Hewitt 1995). There is also evidence from direct observations with nets of a decrease in the number of krill during night in the 0 to $200 \mathrm{~m}$ layer, increasing in the 200 to $400 \mathrm{~m}$ layer (Piatkowski et al. 1994). The ascent of the copepod Metridia gerlachei to surface layers at night has been shown recently (Lopez \& Huntley 1995) as well as vertical movements of copepods at night, increasing the gut pigment during dark and twilight hours (Atkinson et al. 1992a,b). The latter authors did not sample below $180 \mathrm{~m}$, but high abundances of adult specimens of the dominant copepods of Antarctic waters below $200 \mathrm{~m}$ have been observed (Ward et al. 1995). This pattern of diel vertical migration (downward and upward movements during the night for krill and copepods, respectively) has also been observed in stratified sampling in the water column by Park \& Wormuth (1993), although no explanation was given to this pattern. A tentative explanation for the absence of downward diurnal migration of krill could be related to the presence of mesopelagic fishes which feed largely on krill (Lancraft et al. 1989, 1991, Rowedder 1979a,b) and are found by day below $200 \mathrm{~m}$ (Torres \& Somero 1988, Williams \& Duhamel 1994, Duhamel et al. 2000) or at 150 to $300 \mathrm{~m}$ depth as observed from the gut content of king penguins (Pütz \& Bost 1994).

The feeding behaviour of euphausiids and copepods is also consistent with this pattern of vertical distribution and migration. Our observation of a decrease in gut pigment content and an increase in crustacean appendages in the gut of euphausiids coinciding with the twilight and dark hours suggests a switch from plant-based to animal food in those organisms. The switch to animal food agrees with the observation of predatory feeding by krill (Price et al. 1988, Atkinson \& Snÿder 1997) and with the preference of those organisms for animal food in the presence of both phytoplankton and mesozooplankton (Granéli et al. 1993). In fact, it has been observed that the heterotrophic component of diet accounted for an average $79 \%$ of the mass of the gut contents (Perissinotto et al. 2000). Krill is also able to prey on the most common size of large copepods at the fastest rates (Atkinson \& Snÿder 1997). The feeding behaviour studied is also consistent with the observation that during the day almost all the krill faeces were concentrated near the surface while during night they were found deeper (González 1992). Although sinking of large faeces has been postulated to explain this nocturnal distribution (González 1992), the possibility that they could be produced deeper during night-time cannot be ruled out.

This pattern of feeding and vertical migration of both euphausiids and copepods supports the observations that high krill abundance areas are characterised by exceptionally few copepods, and those appeared to live deeper and to make more extensive vertical migrations (Atkinson et al. 1999). The former observation has precedents in the literature. Brinton \& Antezana (1984) found a scarcity of mesozooplankton in areas of high krill densities, and Rakusa-Suszczewski (1982), Hosie (1994) and Voronina et al. (1994) observed an inverse relationship between krill and non-krill organisms in Antarctic waters. Moreover, measurements of mesozooplankton biomass in Antarctic waters reported by Hernández-León et al. (1999) during December 1991, Robins et al. (1995) during November and early December 1992, and Hernández-León et al. (2000) during January 1993 revealed values corresponding to the lowest observed in the literature for Antarctic waters despite the rather high chl a concentrations at 
the same oceanographic stations (Arístegui \& Montero 1995, Robins et al. 1995, Arístegui et al. 1996). Mesozooplankton should not be food limited because a high proportion of primary production is not consumed (see Atkinson \& Shreeve 1995, Dubischar \& Bathmann 1997, Swadling et al. 1997, Hernández-León et al. 1999, among others) and organisms were actively growing as deduced from indices of growth (Hernández-León et al. 2000). Moreover, the energy budget of krill based on autotrophic material during laboratory incubations shows that ingestion rates are generally insufficient to meet their daily requirements (Antenzana et al. 1982, Holm-Hansen \& Huntley 1984, Perissinotto et al. 1997, among others). In which case, the explanation for the low biomass of mesozooplankton (especially large copepods) around the Antarctic Peninsula should be related to predation. It is known that the Bransfield Strait and surrounding waters are areas of high krill densities (Everson \& Miller 1994, Siegel \& Kalinowski 1994); therefore, the potential to diminish the mesozooplankton biomass by predation is also high. This would explain the decrease in mesozooplankton biomass normally observed as we approached the coastal waters from the Polar Front (Foxton 1956, Boysen-Ennen et al. 1991). In fact, a tendency of the copepod biomass to decrease and that of euphausiids to increase southward has been observed (Voronina et al. 1994). This behaviour of krill, which suggests a predation pressure on large copepods and on mesopelagic vertical migrants, would also explain the migration of major parts of the krill stock from under the ice-cover towards open (deeper) waters during the spring-summer months (Siegel 1988, Sprong \& Schalk 1992).

Krill is heavily dependent on the formation and melting of the pack-ice. The inter-annual variability of ice concentration determines the dynamics of krill populations as there is an effect on its spawning and recruitment (Siegel \& Loeb 1995). Ice concentration will determine the development of plankton dynamics and consequent food web effects (bottom-up control) as it influences the stability of the water column as well as the release of ice-algae. However, krill would impose a predatory impact down food webs (top-down control), the effects of which are at present quite unknown. The predatory effect of krill could explain the scarcity sometimes observed of dominant species of copepods in certain areas of the Southern Ocean. Evidence of a top-down control, such as that reported above and also in the literature, is accumulating and shows the importance of predation in relation to the standard bottomup paradigm in biological oceanography. In this context, the tentative suggestion by Kawamura (1986) that the zooplankton composition of Antarctic waters may have changed over the last half century could be con- troversial because his samples were obtained from widely separate regions and could also be affected by the inverse relationship between krill and non-krill zooplankton (Hosie 1994). However, he observed that while zooplankton biomass remained unchanged over the past several decades, during the BIOMASS-SIBEX I cruises (1983-84) herbivorous copepods (Calanus propinquus, Calanoides acutus and Rhincalanus gigas) were only 1 to $10 \%$ as numerous as during the 'Discovery' investigations 60 years ago. The predatory behaviour of a supposed increased population of krill could produce the decrease in abundance of those copepods (see also Atkinson et al. 1999) and would explain the sometimes observed dominance of the copepod Metridia gerlachei, an active vertical migrator (hence better adapted to avoid predation) in locations around the Bransfield Strait (see Park \& Wormuth 1993). It is also suggested that future investigations should study the effect of 'superswarms', which are high densities of krill extending over 2.8 to $21.6 \mathrm{~km}$ (Cram et al. 1979, Mathisen \& Macaulay 1983, Macaulay et al. 1984, Shulenberger et al. 1984, Higginbottom \& Hosie 1989, Siegel \& Kalinowski 1994, Murray et al. 1995, among others), and should also focus on the top-down effect described above because it could produce important changes in the structure of plankton communities in the Southern Ocean.

Acknowledgements. The authors wish to thank H. Dam for his comments and constructive criticisms. The comments made by 5 anonymous reviewers were greatly appreciated. We also thank Carmen Fraga Saavedra for drawing some of the figures. This work was supported by the 'Comisión Interministerial de Ciencia y Tecnología- Programa Antártico' (projects 'Oceanografía del Estrecho de Bransfield, 1991' and 'Oceanografía Dinámica y Productividad en el Estrecho de Bransfield durante el verano austral, 1993').

\section{LITERATURE CITED}

Antezana T, Ray K, Melo C (1982) Trophic behaviour of Euphausia superba Dana in laboratory conditions. Polar Biol 1:77-85

Arístegui J, Montero MF (1995) Plankton community respiration in Bransfield Strait (Antarctic Ocean) during austral spring. J Plankton Res 17:1647-1659

Arístegui J, Montero MF, Ballesteros S, Basterretxea G, van Lenning K (1996) Planktonic primary production and microbial respiration measured by ${ }^{14} \mathrm{C}$ assimilation and dissolved oxygen changes in coastal waters of the Antarctic Peninsula during austral summer: implications for carbon flux studies. Mar Ecol Prog Ser 132:191-201

Atkinson A, Shreeve RS (1995) Response of the copepod community to a spring bloom in the Bellingshausen Sea. DeepSea Res Part II 42:1291-1311

Atkinson A, Snÿder R (1997) Krill-copepod interactions at South Georgia, Antarctica, I. Omnivory by Euphausia superba. Mar Ecol Prog Ser 160:63-76

Atkinson A, Ward P, Williams R, Poulet SA (1992a) Diel verti- 
cal migration and feeding of copepods at an oceanic site near South Georgia. Mar Biol 113:583-593

Atkinson A, Ward P, Williams R, Poulet SA (1992b) Feeding rates and diel vertical migration of copepods near South Georgia: comparison of shelf and oceanic sites. Mar Biol $114: 49-56$

Atkinson A, Ward P, Hill A, Brierley AS, Cripps GC (1999) Krill-copepod interactions at South Georgia, Antarctica, II. Euphausia superba as a major control on copepod abundance. Mar Ecol Prog Ser 176:63-79

Boysen-Ennen E, Hagen W, Hubold G, Piatkowski U (1991) Zooplankton biomass in the ice-covered Weddell Sea, Antarctica. Mar Biol 111:227-235

Brinton E, Antezana T (1984) Structures of swarming and dispersed populations of krill (Euphausia superba) in Scotia Sea and South Shetland waters during January-March 1981, determined by bongo nets. J Crust Biol 4:45-66

Cram DL, Agenbag JJ, Hampton I, Robertson AA (1979) SAS Protea cruise, 1978: The general results of the acoustics and remote sensing study, with recommendations for estimating the abundance of krill (Euphausia superba Dana). S Afr J Antarct Res 9:3-14

Cripps GC, Watkins JL, Hill HJ, Atkinson A (1999) Fatty acid content of Antarctic krill Euphausia superba at South Georgia related to regional populations and variations in diet. Mar Ecol Prog Ser 181:177-188

Demer DA, Hewitt RP (1995) Bias in acoustic estimates of Euphausia superba due to diel vertical migration. DeepSea Res Part II 42:455-475

Dubischar C, Bathmann UV (1997) Grazing impact of copepods and salps on phytoplankton in the Atlantic sector of the Southern Ocean. Deep-Sea Res Part II 44:415-433

Duhamel G, Koubbi P, Ravier C (2000) Day and night mesopelagic fish assemblages off the Kerguelen Islands (Southern Ocean). Polar Biol 23:106-112

Everson I (1982) Diurnal variations in mean volume backscattering strength of an Antarctic krill (Euphausia superba) patch. J Plankton Res Part II 4:155-162

Everson I, Miller DGM (1994) Krill mesoscale distribution and abundance: results and implications of research during the BIOMASS Programme. In: El-Sayed SZ (ed) Southern Ocean ecology, The BIOMASS perspective, Cambridge University Press, New York, p 129-143

Foxton P (1956) The distribution of the standing crop of zooplankton in the Southern Ocean. Discovery Rep 28: 191-236

González HE (1992) The distribution and abundance of krill faecal material and oval pellets in the Scotia and Weddell Seas (Antarctica) and their role in particle flux. Polar Biol 12:81-91

Granéli E, Granéli W, Rabbani MM, Daugbjerg N, Fransz G, Cuzin-Roudy J, Alder V (1993) The influence of copepod and krill grazing on the species composition of phytoplankton communities from the Scotia-Weddell Sea. An experimental approach. Polar Biol 13:201-213

Hernández-León S, Torres S, Gómez M, Montero I, Almeida C (1999) Biomass and metabolism of zooplankton in the Bransfield Strait (Antarctic Peninsula) during austral spring. Polar Biol 21:214-219

Hernández-León S, Almeida C, Portillo-Hahnefeld A, Gómez M, Montero I (2000) Biomass and potential feeding, respiration and growth of zooplankton in the Bransfield Strait (Antarctic Peninsula) during austral summer. Polar Biol 23: $679-690$

Higginbottom JR, Hosie GW (1989) Biomass and population structure of a large aggregation of krill near Prydz Bay, Antarctica. Mar Ecol Prog Ser 58:197-203
Holm-Hansen O, Huntley M (1984) Feeding requirements of krill in relation to food sources. J Crust Biol 4:156-178

Hopkins TL, Torres JJ (1989) Midwater food web in the vicinity of a marginal ice zone in the western Weddell Sea. Deep-Sea Res 36:543-560

Hosie GW (1994) The macrozooplankton communities in the Prydz Bay region, Antarctica. In: El-Sayed SZ (ed) Southern Ocean ecology. The BIOMASS perspective. Cambridge University Press, New York, p 93-123

Kawamura A (1986) Has marine Antarctic ecosystem changed? A tentative comparison of present and past macrozooplankton abundances. Mem Natl Inst Polar Res (Jpn), Spec Issue 40:197-211

Lancraft TM, Torres JJ, Hopkins TL (1989) Micronekton and macrozooplankton in the open waters near ice edge zones (AMERIEZ 1983 and 1986). Polar Biol 9:225-233

Lancraft TM, Hopkins TL, Torres JJ, Donelly J (1991) Oceanic micronektonic/macrozooplanktonic community structure and feeding in ice covered Antarctic waters during the winter (AMERIEZ 1988). Polar Biol 11:157-167

Lopez MDG, Huntley ME (1995) Feeding and diel vertical migration cycles of Metridia gerlachei (Giesbrecht) in coastal waters of the Antarctic Peninsula. Polar Biol 15: 21-30

Macaulay MC, English TS, Mathisen OA (1984) Acoustic characterization of swarms of Antarctic krill (Euphausia superba) from Elephant Island and Bransfield Strait. J Crustac Biol 4:16-44

Mackas DL, Bohrer R (1976) Fluorescence analysis of zooplankton gut contents and an investigation of diel feeding patterns. J Exp Mar Biol Ecol 25:77-85

Mathew KJ (1988) Net avoidance behaviour among larval, juvenile, and adult euphausiids. J Mar Biol Assoc India 30: 93-98

Mathisen OA, Macaulay MC (1983) The morfological features of a super-swarm of krill, Euphausia superba. Mem Natl Inst Polar Res 27:153-164

Morales CE, Bautista B, Harris RP (1990) Estimates of ingestion in copepod assemblages: gut fluorescence in relation to body size In: Barnes M, Gibson RN (eds) Trophic relationships in the marine environment. Aberdeen University Press, p 565-577

Murray AWA, Watkins JL, Bone DG (1995) A biological acoustic survey in the marginal ice-edge zone of the Bellingshausen Sea. Deep-Sea Res Part II 42:1159-1175

Nishino Y, Kawamura A (1994) Winter gut contents of Antarctic krill (Euphausia superba Dana) collected in the South Georgia area. Proc NIPR Symp Polar Biol 7:82-90

Nishikawa J, Naganobu M, Ichii T, Ishii H, Terazaki $M_{\text {, }}$ Kawaguchi K (1995) Distribution of salps near the South Shetland Islands during austral summer, 1990-1991 with special reference to krill distribution. Polar Biol 15:31-39

Nishino Y, Kawamura A (1996) Food habits of the Antarctic krill Euphausia superba Dana in South Shetland waters. Bull Plankton Soc Jpn 43:9-19

Nordhausen W (1994) Winter abundance and distribution of Euphausia superba, E. crystallorophias, and Thysanoessa macrura in Gerlache Strait and Cristal Sound, Antarctica. Mar Ecol Prog Ser 109:131-142

Pakhomov EA, Perissinotto R, McQuaid CD (1994) Comparative structure of the macrozooplankton/micronekton communities of the subtropical and Antarctic Polar fronts. Mar Ecol Prog Ser 111:155-169

Pakhomov EA, Perissinotto R, Froneman PW, Miller DGM (1997) Energetics and feeding of Euphausia superba in the South Georgia region during the summer of 1994. J Plankton Res 19:399-423 
Park C, Wormuth JH (1993) Distribution of Antarctic zooplankton around Elephant Island during the austral summers of 1988, 1989, and 1990. Polar Biol 13:215-225

Perissinotto R, Pakhomov EA, McQuaid CD, Froneman PW (1997) In situ grazing rates and daily ration of Antarctic krill Euphausia superba feeding on phytoplankton at the Antarctic polar front and the marginal ice zone. Mar Ecol Prog Ser 160:77-91

Perissinotto R, Gurney L, Pakhomov EA (2000) Contribution of heterotrophic material to diet and energy budget of Antarctic krill, Euphausia superba. Mar Biol 136:129-135

Piatkowski U, Rodhouse PG, White MG, Bone DG, Symon C (1994) Nekton community of the Scotia Sea as sampled by the RMT 25 during austral summer. Mar Ecol Prog Ser 112:13-28

Price HJ, Boyd KR, Boyd CM (1988) Omnivorous feeding behaviour of the Antarctic krill Euphausia superba. Mar Biol 97:67-77

Pütz K, Bost CA (1994) Feeding behavior of free-ranging king penguins (Aptenodytes patagonicus). Ecology 75: 489-497

Quetin LB, Ross RM, Clarke A (1994) Krill energetics: seasonal and environmental aspects of the physiology of Euphausia superba In: El-Sayed SZ (ed) Southern Ocean ecology. The BIOMASS perspective. Cambridge University Press, New York, p 165-184

Rakusa-Suszczewski S (1982) The relationship between the distribution of plankton biomass and plankton communities in the Drake Passage and the Bransfield Strait (BIOMASS-FIBEX, February-March, 1981). Mem Nat Inst Polar Res (Jpn), Spec Issue 27:77-83

Robins DB, Harris RP, Bedo AW, Fernandez E, Fileman TW, Harbour DS, Head RN (1995) The relationship between suspended particulate material, phytoplankton and zooplankton during the retreat of the marginal ice zone in the Bellingshausen Sea. Deep-Sea Res Part II 42: $1137-1158$

Rowedder U (1979a) Some aspects of the biology of Electrona antarctica (Gunther, 1878) (Family Myctophidae). Meeresforschung 27:244-251

Rowedder U (1979b) Feeding ecology of the myctophid Electrona antarctica (Gunther, 1878) (Teleostei). Meeresforschung 27:252-263

Sameoto DD, Jaroszynski LO, Frase WB (1980) BIONESS, a new design in multiple net zooplankton samplers. Can J Fish Aquat Sci 50:334-346

Shulenberger E, Wormuth JH, Loeb VJ (1984) A large swarm

Editorial responsibility: Otto Kinne (Editor),

Oldendorf/Luhe, Germany of Euphausia superba: overview of patch structure and composition. J Crustac Biol 4:75-95

Siegel V (1988) A concept of seasonal variation of krill (Euphausia superba) distribution and abundance west of the Antarctic Peninsula In: Sahrhage D (ed) Antarctic Ocean and resources variability. Springer-Verlag, New York, p 219-230

Siegel V, Kalinowski J (1994) Krill demography and smallscale processes: a review In: El-Sayed SZ (ed) Southern Ocean ecology. The BIOMASS perspective. Cambridge University Press, New York, p 145-163

Siegel V, Loeb V (1995) Recruitment of Antarctic krill Euphausia superba and possible causes for its variability. Mar Ecol Prog Ser 123:45-56

Sprong I, Schalk PH (1992) Acoustic observations on krill spring-summer migration and patchiness in the northern Weddell Sea. Polar Biol 12:261-268

Strickland JDH, Parsons TR (1972) A practical handbook of seawater analysis. Fish Res Board Can Bull 167:1-310

Swadling KM, Gibson JAE, Ritz DA, Nichols PD, Hughes DE (1997) Grazing of phytoplankton by copepods in eastern Antarctic coastal waters. Mar Biol 128:39-48

Torres JJ, Somero GN (1988) Vertical distribution and metabolism in Antarctic mesopelagic fishes. Comp Biochem Physiol 90B:521-528

Voronina NM, Kosobokova KN, Pakhomov EA (1994) Composition and biomass of summer metazoan plankton in the 0-200 m layer of the Atlantic sector of the Antarctic. Polar Biol 14:91-95

Ward P, Atkinson A, Murray AWA, Wood AG, Williams R, Poulet SA (1995) The summer zooplankton community at South Georgia: biomass, vertical migration and grazing. Polar Biol 15:195-208

Weeks AR, Griffiths G, Roe H, Moore G, Robinson IS, Atkinson A, Shreeve R (1995) The distribution of acoustic backscatter from zooplankton compared with physical structure, phytoplankton and radiance during the spring bloom in the Bellingshausen Sea. Deep-Sea Res Part II 42: 997-1019

Williams R, Duhamel G (1994) Studies on fish of the Indian Ocean sector of the Southern Ocean during BIOMASS Programme. In: El-Sayed SZ (ed) Southern Ocean ecology. The BIOMASS perspective. Cambridge University Press, New York, p 211-229

Yentsch CS, Menzel DW (1963) A method for the determination of phytoplankton chlorophyll and phaeophytin by fluorescence. Deep-Sea Res 10:221-231

Submitted: April 17, 2000; Accepted: March 22, 2001

Proofs received from author(s): November 15, 2001 